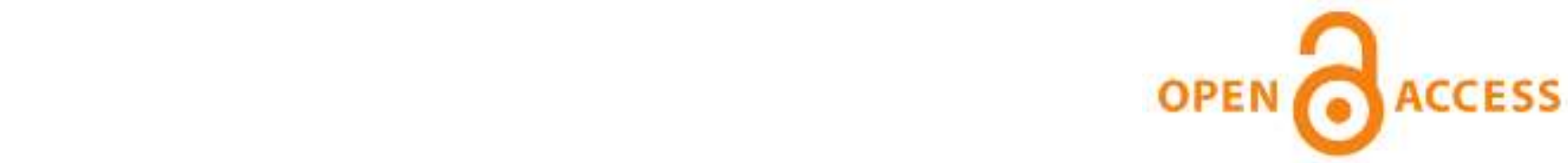 \\ International Journal of Social Sciences and Management \\ A Rapid Publishing Journal
}

ISSN 2091-2986

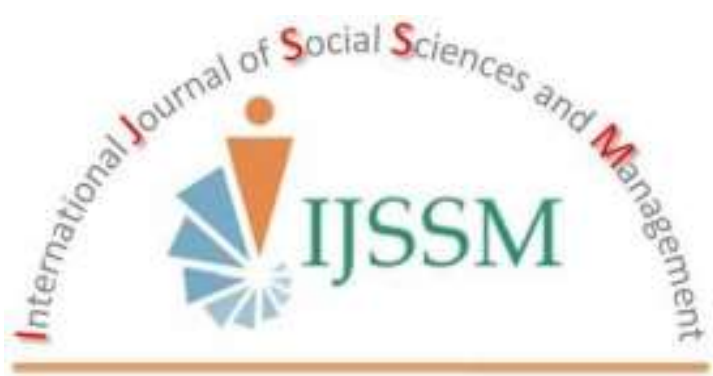

\section{Indexing and Abstracting}

CrossRef, Google Scholar, International Society of Universal Research in Sciences (EyeSource), Journal TOCs, New Jour, Scientific Indexing Services, InfoBase Index, Open Academic Journals Index (OAJI), Scholarsteer, Jour Informatics, Directory of Research Journals Indexing (DRJI), International Society for Research Activity (ISRA): Journal Impact Factor (JIF), Simon Fraser University Library, etc.

Vol- 2(4), October 2015 


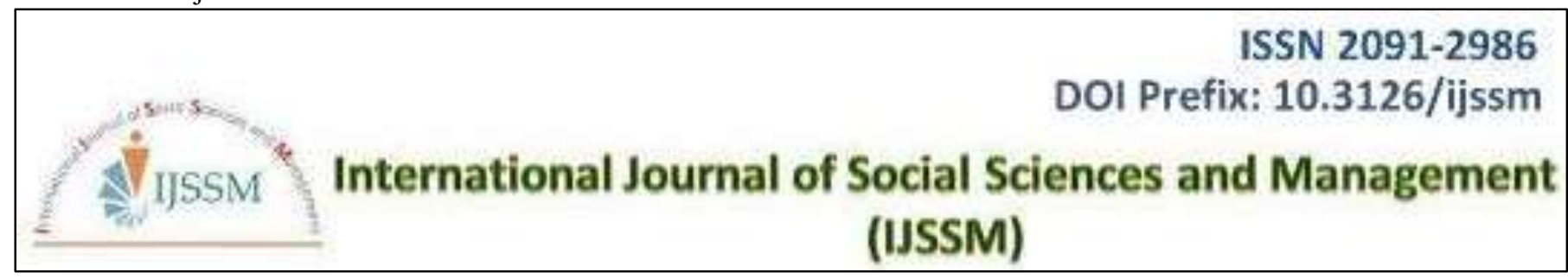

Research Article

\title{
KASHMIRI ORPHAN: FRAGILE SECTIONS OF SOCIETY
}

\author{
Irshad Ahmad Irshad \\ Department of Education, Barkatullah University, Bhopal, India \\ Email: irshadeducation@gmail.com
}

\begin{abstract}
The future of child wholly and solely depends upon parents their mentality, their behavior, their assets etc. A family with sound economy can make their children sound in all walks of life. But unfortunate thing for an orphan is that he/she lacks this valuable guardian i.e, parents. The children lost the parental support while as thousands of families lost their bread earners. How an orphan can survive smoothly in this expensive and cunning world. So far as orphan of Jammu and Kashmir are concerned, they are in constant strain, anxiety, stress due to the situation of armed conflict from last two decades and Kashmir region in particular has been the most affected. The conflict has led to the loss of human resource and caused infrastructural damage to some of the important institutions. Here the orphan number is far beyond than normal as compared to other states of India. In this paper it is an attempt to showcase the condition, challenges and the position of orphans in Kashmir region. It also mentions the role of government in attempting to reduce the number of orphans and in the rehabilitation of conflict affected victims.
\end{abstract}

Keywords: Orphan; Educational loss; Exploitation; Orphanages; Armed conflict; NGO.

\section{Introduction}

In Kashmir, the initiation of armed conflict in late 1980's has witnessed of life. The every section of society got affected either through the death of bread winner, injury, torture or disappearance. Most families of Kashmir fall within the middle class, the primary bread winner being particularly the professional or skilled labor and it becomes difficult for a family to run livelihood option, if there happens any infirmity to earner. Most of the adults including youth were abused, dishonored and brutally treated. The women being second most victims after children. (Victoria, 2004) In most families here, especially among the middle class, the husband was the skilled professional or labor and therefore the bread winner for the family. If he became unemployed or loses work hours, his wife can take on a menial job to help and get the families through the difficult period. However, if he lost his wife and children are almost certainly leave woman destitute and children orphaned. (Dabla, 1999)

\section{Definition of Child}

A child is primarily defined by age, with most common agreement being less than 18 years. (Ibid) In some cases, it was increased to 21 years. However, it is concerned with the respondent like the state. The age range $18-20$ years is being considered as early adulthood. (Adil, 2010) Census of India defines persons below the age of 14 years as children. According to the Article-1 UN Convention on Rights of Child 1989, a child means every human being below the age of 18 years, under the law applicable to the child, majority is attained earlier. Hence, the word child has been used in various legislation as a term denoting relationship and term indicating capacity. (Dabla, 2010)

\section{Definition of Orphan}

According to the online Encyclopedia Britannica and Merriam-Webster dictionary on orphan is:-

$>$ A child deprived by death of one or usually both parents.

$>$ A young animal that has lost its mother and

$>$ One deprived of some protection or advantagese.g. orphans of the conflict.

Most accepted definition of orphan is a child who has lost both parents through death. This definition is extended in most of the groups including the loss of parents through absconding or the parents are unable or unwilling to provide care. (Skinner, 2004)

UNICEF and numerous International Organizations adopted the broader definition of orphan in the mid 1990's as the AIDS Pandemic began leading to the death of millions of parents worldwide, leaving an ever increasing number of children growing up without one or mere parents. So, the terminology of a single orphan-the loss of one parent and a double orphan-the loss of both parents was born to convey this growing crisis.

The absence of guardian's certainty increased the potential of the vulnerability of the child especially orphan. In many 
countries, orphans are divided into two groups, one with guardians and another without guardians. This refers that being an orphan doesn't necessarily mean being a vulnerable. (Skinner, 2004)

\section{Vulnerable Child}

A vulnerable child is seen as someone who has no or very restricted access to basic needs. They may have both parents, but the child rights might to segregate. The definition of vulnerability is felt to reflect certain aspects in the context of the child. Thus, the vulnerability is contextualized as a child not having certain basic rights fulfilled and identification of problems in the environment of the child. (Dabla, 2010)

UNICEF estimates that Kashmir has a 100,000 special or orphaned children- a sizable percentage of the population and one whose fate will determine the overall development of Kashmiri society. Before the 1990's, a relative or neighbor in accordance with religious and social practice would adopt an orphan. (Machel, 2005)

Thousands of single parent orphans of Kashmir strive in their own way to survive. Majority of them struggle for funding themselves and their dependents. Those who are lucky manage to gain entry in orphanages and secure their physical survival. However, majority are beyond the four walls of orphanages. (Dabla, 2010)

\section{Challenges to Orphans in Kashmir}

With the increase in number of orphans in Kashmir, which had a direct impact on the meager resources allocated to them hence, resulted in manifold challenges and challenges increasing day to day? The challenges can be conceptualized as follows: (Dabla, 1999)

Accommodation Problems: This type of vulnerability exists to the orphan children who have lost their parents. Since Kashmiri society allows widows remarriage which has a direct ramification on the orphan, making them dishonored from maternal support. (Dabla, 2010) Hence, orphans were felt with one option that was orphanages. The second factor that makes the orphan to approach orphanages was little support from relatives, friends and community members. The third factor is the economic dependency of orphans making them vulnerable to get shelter at orphanages.

Educational Loss: The frequent attacks on education institutions had an alarming impact on children's education. Security forces have used school buildings as barracks, thus putting them out of bounds. 2297 adults and non-formal education centers have closed in the region since 1990 due to financial constraints and staff shortages. But, the orphan in Kashmir has different story in-terms of their educational status. (Madhosh, 2000) Due to economic and social debasement, these orphans were all together unable to study in schools.
(Jayratha, 2001) Moreover the educational curriculum followed by different orphanages was not based on modern pattern; many orphanages were only focusing on religious education only. Thus, disparity and deprivation exists in-terms of education of orphan.

Psychological Problems: Most of the orphanages were the victims of armed conflict in Kashmir. It doesn't matter where they live; the impact on their mental health has been inevitable phenomenon. There is presence of anxiety, stress, PTSD among the children in Kashmir and orphan in particular. (Prasad, 2000) It has remained evident as a result of conflictual situations, that these orphans have experienced in past. The need of an hour has resulted in an institutional care for orphanages, but these orphanages are not desirable for orphans, as they are the result of armed conflict with strong psychological trauma. (Margoob, 2006)

Social Dis-organization: Due to the parental loss, the orphans in Kashmir had suffered on social grounds like family, marriage and kinship. The primary socialization of orphans has got disorganized, with dis-organization of family as a unit. In this social environment whether the traditional patriarchal authority couldn't be established nor could the traditional norms and values be maintained. As a result, there was significant degree of erosion to the valuation ethos and social control mechanism with the outside their families. (State Government of Jammu and Kashmir, 2009)

Health Problems: The conflict in Kashmir has led to increase in neurological, cardiological, psychological and oncological diseases. (De-Jong, 2000) The pathetic aspect of this situation is that orphans are not in a position to get proper treatment. The lack of service access in the health sector also poses threat to the health scenario of orphan. The absence of balanced nutrition has also the direct consequences on the health of orphan like fatigue, constipation, eye burning etc. are the common health issues. (Voluntary Health Association of IndiaVHAI, 2000)

Dependence: Most of the orphans have either become partially dependent or totally dependent on others, who include relatives, friends, neighbor and community members. The orphans residing indifferent orphanages are entirely dependent on orphanages resources. However the material dependence is fulfilled in orphanages but the psychological dependence in a big lacuna. (Mohammad, 2009)

\section{Governmental Response}

Indian constitution highlights the need and significance of providing orphan protection and assistance. It mentions, 
"All citizens have equally before law" Article-10 of it states that, "A child permanently or temporarily deprived of his family environment for any reasons shall be entitled to special protection and assistance provided by the state". Article-39(e) and (f) of the Indian constitution says, "That state must direct its policy towards securing that the children are not forced by economic necessity to enter vocation unsuited to their age and strength and that childhood and youth are protected against exploitation and against moral and material abandonment". (CRC, 1998)

There are four major guidelines given by United Nations Convention on Right of Child, ratified by India in 1992. The need for such guidelines is of utmost importance for orphans of Kashmir. The state government showed a feeble role in promoting the interest of orphans. There is no comprehensive policy of state government for the orphans. The earlier response that the state government started providing a job and exgratia financial payment of Rs.50.000/= which later on raised to Rs.100,000/= to the next of kin of deceased person.

The Jammu and Kashmir council for Rehabilitation of Victims of Militancy Scheme (VOM) under which the orphans for the conflict are assisted financially. The financial assistance helps under the scheme to orphans in following ways:

$>$ Orphans studying from Ist. Standard to $5^{\text {th }}$ standard, primary Rs.200/= per-month.

$>$ Orphans studying from $6^{\text {th }}$ Standard to $8^{\text {th }}$ standard, started Rs.250/= per-month.

$>$ Orphans studying from $9^{\text {th }}$ Standard and $10^{\text {th }}$ standard, started to Rs.300/=per-month.

> (State Government of Jammu and Kashmir, 2009; UNICEF, 1999)

\section{International Response}

The United Nations Declaration presents a code for the wellbeing of every child, "Without any exception whatsoever" and "Without distinction or discrimination on account of race, colour, sex, language, religion, political or other opinion, national or social origin, property, other status whether of himself or of his family". (Elisabeth, 2003)

The United Nations, in the Declaration of the Rights of the Child again says, "The child by reason of physical and mental immaturity needs special treatment, education and care required by his particular condition. The child shall be protected against all forms of neglect, cruelty and exploitation. (Bhavan, 2000)

The United Nations adopted the Comprehensive Convention of the Rights of Child in 1989. The preamble to the convention, recognizes that, "The child, for the full and harmonious development of his/her personality, should grow up in a family environment, in an atmosphere of happiness, love and understanding" and considers that, "The child should be fully prepared to live an individual life in society brought up in the spirit of the ideas proclaimed in the charter of the United Nations and particular in the spirit of peace, dignity, tolerance, freedom, equality and solidarity. (State Government of Jammu and Kashmir, 2009)

\section{Need of Study}

The orphan and orphanages in Kashmir have developed into a challenge in Kashmir. There was little number of orphans prior to two decades. Such orphans were under the traditional support system, which involved the guardianship of joint family system; within such system orphans weren't facing the problems of food, shelter, clothing etc. The other component that was in traditional support system was the local community, taking care of these orphans in absence of guardians.

The two decades long conflict has made a paradigm shift in relation to care and protection of orphans. There has been increased number of orphans as a result of loss of life due to armed conflict. Since it has also led to disruption in entire social, economic and political spheres. Hence it has rendered the orphans without care and protection.

With the arena NGO's stepped in and thus led to the establishment of orphanages. The establishment of orphanages was the only immediate support system for orphans with the passage of time not only the number of orphans increased but also the number of orphanages. Over a period of time it rendered the orphanages as indispensable part of society.

In the present context the need emerges to the study, the role of orphanages, social stigma of orphanages and economic problems. It becomes incumbent to assess the role of orphanages through their basic services like accommodation, food, clothing, education, recreation etc. The need is also to identify whether there are inconformity with the minimum standard, whether these are at par with national and international standard.

The orphanages in Kashmir are altogether lacking the licensing system, which is the key indicator guaranteeing basic service up to certain standards by their regulatory nature. The orphanages are however found to be having the legal status, being registered under the Trust Act and Societies Registration Act, but such legal status doesn't prescribe and regulate the role of orphanages.

Moreover the social stigma that is related to such orphanages has a direct impact on psychology of orphan and needs to be given a critical assessment. The economic problems of orphanages and their impact on their role becomes subject of study.

\section{Objectives of Study}

* To carry out investigation about nature of conflict situations in Kashmir and its implications to the childrens of Kashmir. 
* To carry out the objective study about the life and living conditions of orphans due to conflict situation.

* To analyze objectively the response of the society and of the state towards the problems of orphans in Kashmir.

* To make an objective assessment of the role of orphanages in Kashmir in responding to the critical problem of orphans in the social, psychological, economic, cultural, health and other related fields.

* To make a presentation of suggestions for policy formulation and its implication on the part of government and specific realistic suggestions to be implicated by local orphanages.

\section{Tools and Techniques of Data Collection}

After understanding some ideas and understanding the field and working out of universe the research plans, how to assess the field. These main techniques of data collection; one is intensive field work method and other is survey method. Intensive field work method include observation, interview, case study etc. often the researcher uses one as more methods to collect data, taking into consideration the nature of investigation, objectives and scope of inquiry, financial resources and the availability and degree of accuracy. The data to be collected would need to adequate and dependable.

The present study was empirical one; the data was collected from both primary as well as secondary sources. The primary collection of data included the employment of Structural Interview Schedule (SIS) and observation. The Structural Interview Schedule (SIS) was with orphans, sponsors of orphanages and managers of orphanages. However, a separate schedule was prepared for orphans. The schedule included both open ended and closed ended question and was employed with great precisions to get accurate and unbiased data. The observation was also followed, assessing the services and activities of orphanages like lunch, prayers, playing. The collection included direct participation in the activities of orphanages and also interviewing in between with other activities. Since the Structural Interview Schedule (SIS) was to be employed with the 20 orphans in each orphanage, hence the orphans were selected in randomly. The employment of Structural Interview Schedule (SIS) continued for 4-5 days in each orphanage.

The secondary sources include books, journals, research papers, official reports, evaluation reports of orphanages etc. this secondary information was also report writing.

\section{Results}

\section{Finding-1}

The findings of present work are divided into two sets. The first set deals with opinion of sponsors and managers of orphanages. The second set deals with the opinion of orphans regarding their respective orphanages. The five orphanages were selected for the purpose of study. Hence, for both the sections of findings; the sample for data collection remained same. The interview schedule was employed with sponsors and managers of the particular orphanages.

From five orphanages, two persons each from orphanage were taken in the study. The designation of these personnel was varying from orphanage to orphanage. In the random sample, five persons were taken with designation as manager, three as warden and two as chairman. Among the sample of 10 respondents only one respondent was female with designation as warden; all the respondents were in the age group of 30 years to 65 years. The educational status of the respondents was, five studied up to bachelor's level, three up to $12^{\text {th }}$ standard and two up to $10^{\text {th }}$ standard. All the five orphanages showed absence of professionals for care and protection of orphans.

The duration of work of the respondents at orphanage varied from 3 years to 15 year in these or different orphanages. The nature of work, these respondents was ranging from management of orphanage affairs, administration of orphanage and care taking supervision of orphans.

In these 5 orphanages, 4 are registered under Trust Act or Societies Registration Act, and only one orphanage is unregistered. Among five, only one orphanage has been established prior to 1990 , while rest 4 were established after 1990.

\section{Finding-2}

The part second of the findings deal with the opinion of orphan about services provided to them by orphanages. The five orphanages were selected for the purpose of study. Hence for both the sections of findings; the source for data collection remained same. Each orphanage was given unit size for sampling equal to twenty in order to collect data from orphan's opinion, thus in total, this chapter involves the sample size that is 100 orphans. The various orphanages which were taken under the study were J\&K Yateem Khanna Gulshan Mahal Hawal, Al Mahmud Children Home, Banat Gopalpora, Gulshan Mahal B Soura.

The total number of orphans, which is hundred, had been taken within the age group of 6-18 years. This was taken in view to have an orphan who has completed the 6 years of age but not completed the 18 years. Further the orphans were categorized into following age groups:

$$
\begin{aligned}
& \text { I. 6-12 years. } \\
& \text { II. 13-18 years. }
\end{aligned}
$$

After the collection of data it is found that $32 \%$ of orphans were in between the age group of 6-12 years and 58\% of orphans were in the age group of 13-18 years. Among the selected orphanages only one orphanage was for the females (Banat). The representation of orphans on the basis of sex ratio was $80 \%$ males and only $20 \%$ females. The disproportionate representation in terms of sex ratio was 
due to the fact that only few orphanages are accommodating girl child orphans.

The original residence of orphans was assessed in terms of rural and urban. After the data collection, it was found $94 \%$ of the orphans were from rural areas and only $6 \%$ from the urban areas. The rural urban categorization was done on the municipal categories, which has already categorized the rural and urban areas in terms of the population density.

All the respondents were found to be school going, however, the nature of schooling is varying from orphanages to orphanages, which will be explained in the proceeding tables and inferences. Further it was found in the study that $28 \%$ of the respondent was studying below $5^{\text {th }}$ standard; this shows the disparity between the age of orphan and his standard in which he/she studies. Only $10 \%$ of the respondents were found studying in $5^{\text {th }}$ standard, the $37 \%$ were studying in the $6^{\text {th }}, 7^{\text {th }}, 8^{\text {th }}$ and $9^{\text {th }}$ standard. It was also found that $24 \%$ of the orphans were studying in the $10^{\text {th }}$ standard and only one orphan was studying in the intermediate level. The other fact that number of orphans being low in higher class was due to their maximum residence age 17-18 years at orphanage. Consequently, such orphans leave the orphanages.

The present study divulges that $52 \%$ of orphan had father in either skilled labour, causal labour and self-employed which showed the economic background of such orphans who were residing in such orphanages. About half of orphans in such orphanages are the direct victims of violence. Another reason that has made these orphans to get shelter in such orphanages in the poverty of their relatives, with the absence of primary breadwinner consequently, only option for such orphans remain to get haven at orphanages.

The education of orphans at orphanages entirely depended on the private institutions. Either the schooling of orphans was done at orphanage or at private schools. Very little number of orphans was getting education at government schools. It reveals the role of government orphanages. The number of orphans who receive the benefits from Social welfare Department was also little. Moreover, these beneficiaries receive very less monetary assistance which makes it hard for such orphans to be self-sufficient and selfreliant.

It can be thus said that the role of orphanages in mixture of success and failures, the success they meet in rehabilitating the orphans and meeting their basic necessities of life. The failures are in the sense that services were not confirming the standards as prescribed by the society, state and International Legal Instruments

\section{Recommendations}

$\checkmark \quad$ The fulltime case worker must be present in each orphanages with a least one case worker for 50 orphans. The case worker in such setting shall facilitate orphans having varied number of problems and will address those problems individually.

$\checkmark \quad$ The stake holders should trace the orphans beyond 18 years of age and necessary policy must be followed for their continuity of education or vocational trainings.

$\checkmark$ Since orphans being vulnerable children, hence their sound development depends in their recreation, leisure and play; a proper focus should be given.

$\checkmark$ The orphanages must need to track the health records of each individual and need to be maintained that. Since most of the orphanages were found to be using the unbalanced diet. It becomes thus necessary to have balanced diet chart prepared with expert consultation and there is need for such chart to be strictly followed. It will have positive implication on the decrease in number of physical and mental health problems.

$\checkmark$ Orphans must be allowed to interact with the world outside their orphanages. Thus need is to foster orphans for interaction with people outside orphanage. Further, they being considered as vulnerable and susceptible to deviant behavior the proper regulatory atmosphere can be followed to check such behavior.

$\checkmark \quad$ The locally used names of orphanages like Yateem Trust and Yateem Khanna must be replaced by more attractive names, which will reduce the stigma among the orphans.

$\checkmark$ Most of orphanages are registered under Trust Act, but only mere registration under trust doesn't serve the purpose of regulating such orphanages thus the need is to have a comprehensive policy from state, which will fix the minimum standards for orphanages so far as the house activities are concerned.

$\checkmark \quad$ The policy must ratify the various National and International Rights of children. The focus of such activity will make orphanages in conformity with International standards and International Rights like Convention on Rights of Children.

\section{Conclusion}

Armed conflict is the use of armed violence to resolve local, national or international disputes between individuals and groups that have a political, economic, cultural or social origin. Hence conflict has been an inevitable phenomenon in every society and has various causes to erupt any point of time. The $20^{\text {th }}$ century has witnessed hundreds of armed conflicts ranging from international, national and at local levels.

The two decades long armed conflict in Kashmir has involved the combination of both high-tech war fare and traditional weaponary". This verity has led to heavy toll of 
civilians in wide range of situation. Consequently, either the causality lead to direct death of child or rendered the child as orphan. The factors such as separation of children's from families, poverty, death of family member and discord have made it mandatory for orphans to get shelter at every expense.

The earliest response to problems of orphans came from family and kin groups members. But, this type of help neither remained sustainable nor organized for huge number of orphans. The governmental response was also feeble as it lacks comprehensive policy for them. Thus, one of the outcomes of last two decades armed conflict in Kashmir has been large number of orphanages.

\section{References}

Adil B (2010) Traditional Rehabilitation and Care of Children without Parental Support, Kashmir: Journal of Kashmir Studies Kashmir.

Bhavan SP (2000) National Human Rights Commission Annual Report 1998-99: New Delhi. National Human Rights Commission.

CRC (1998) The Convention on the Rights of the Child. The Alternate Report: India, New Delhi.

Dabla B (1999) Report on the Research Project Impact of Conflict Situations on Women and Children in Kashmir. SCF. North-West India.

Dabla BA (2010) A Sociological study of Widows and Orphans in Kashmir. Srinagar: Jay Kay Publishers Srinagar, J\&K.

De-Jong K (2000) Kashmir Heaven on Earth. Psychological Consequences of Chronic Emergency. MSF-Holland.

Elisabeth R (2003) Social Work and human Rights: Policy and Pratice. Columbia University Press.
Ibid pp. 14-188.

Jayratha S (2001) Trauma Reactions in Jammu and Kashmir- A Multi- Dimensional Approach.

Machel G (2005) Impact of Armed Conflict on Children. C. Hurst \& Co.

Madhosh AG (2000) Effect of Mental Stress on Health in Kashmir Valley: Paradise in Trauma. Srinagar: University of Kashmir. Srinagar, J\&K.

Margoob M (2006) Psychiatric Disorders among Children Living in Orphanages, Experience from Kashmir. JK Practioners, International Journal of Current Medical Science and Practice.

Mohammad SW (2009) Islam and Khidmat Khalaq. Srinagar: Khidmat Publishing Centre.

Prasad B (2000) Children under Distress. Workshop held in Srinagar. J\&K on 09-12 November 2000.

Skinner D (2004) Defining Orphan and Vulnerable Children. HSRC Publications South Africa, p-08.

State Government of Jammu and Kashmir (2009) State Report, Jammu and Kashmir State. November 2009, Government of Jammu and Kashmir. Ministry of Social Welfare.

State Government of Jammu and Kashmir (2009) State Report: Jammu and Kashmir State Convention son the Rights of the Child.

UNICEF (1999) A Programme for Special Assistance for Children and Women Affected by Armed conflict in Srilanka 200001. Colombo. UNICEF.

Victoria S (2004) Kashmir in Conflict .India; Viva Books, pp-0147.

Voluntary Health Association of India (VHAI) (2000) Pilot Study on Mental Health needs Assessment in Kashmir. 